\title{
Unemployment Benefits Crowd Out Nascent Entrepreneurial Activity
}

\author{
Philipp Koellinger and Maria Minniti
}

\begin{tabular}{|l|l|}
\hline \multicolumn{2}{|l|}{ ERIM REPORT SERIES RESEARCH IN MANAGEMENT } \\
\hline ERIM Report Series reference number & ERS-2008-012-ORG \\
\hline Publication & March 2008 \\
\hline Number of pages & 9 \\
\hline Persistent paper URL & http://hdl.handle.net/1765/11808 \\
\hline Email address corresponding author & koellinger@few.eur.nl \\
\hline Address & Erasmus Research Institute of Management (ERIM) \\
& RSM Erasmus University / Erasmus School of Economics \\
& Erasmus Universiteit Rotterdam \\
& P.O.Box 1738 \\
& 3000 DR Rotterdam, The Netherlands \\
& Phone: + 31104081182 \\
& Fax: $\quad+31104089640$ \\
& Email: info@erim.eur.nl \\
& Internet: $\quad$ www.erim.eur.nl \\
\hline
\end{tabular}

Bibliographic data and classifications of all the ERIM reports are also available on the ERIM website: www.erim.eur.nl 
ERASMUS RESEARCH INSTITUTE OF MANAGEMENT

\section{REPORT SERIES}

\section{RESEARCH IN MANAGEMENT}

\begin{tabular}{|c|c|}
\hline \multicolumn{2}{|c|}{ ABSTRACT AND KEYWORDS } \\
\hline Abstract & $\begin{array}{l}\text { Analyzing a cross-country panel of } 16 \text { OECD countries from } 2002 \text { to } 2005 \text {, we find that higher } \\
\text { unemployment benefits crowd out nascent entrepreneurial activity. Our results hold regardless of } \\
\text { entrepreneurial motivation (necessity or opportunity) and entrepreneurial type (imitative or } \\
\text { innovative). }\end{array}$ \\
\hline Free Keywords & entrepreneurship, business startups, unemployment benefits \\
\hline Availability & $\begin{array}{l}\text { The ERIM Report Series is distributed through the following platforms: } \\
\text { Academic Repository at Erasmus University (DEAR), DEAR ERIM Series Portal } \\
\text { Social Science Research Network (SSRN), SSRN ERIM Series Webpage } \\
\text { Research Papers in Economics (REPEC), REPEC ERIM Series Webpage }\end{array}$ \\
\hline Classifications & $\begin{array}{l}\text { The electronic versions of the papers in the ERIM report Series contain bibliographic metadata } \\
\text { by the following classification systems: } \\
\text { Library of Congress Classification, (LCC) LCC Webpage } \\
\text { Journal of Economic Literature, (JEL), JEL Webpage } \\
\text { ACM Computing Classification System CCS Webpage } \\
\text { Inspec Classification scheme (ICS), ICS Webpage }\end{array}$ \\
\hline
\end{tabular}




\title{
Unemployment benefits crowd out nascent entrepreneurial activity
}

\author{
Philipp Koellinger (a) (b) (c) (d), Maria Minniti (e)
}

Submitted version ( $v 1.0)$

Date of completion of manuscript: 18 March 2008

(a) Erasmus University Rotterdam, School of Economics, Department of Applied Economics, P.O. Box 1738, 3000 DR Rotterdam, Netherlands; Email: koellinger@few.eur.nl, Tel.: +3110- 4089141, Fax: +31-10-4089141

(b) Tinbergen Institute, Rotterdam, NL

(c) Erasmus Research Institute of Management, Rotterdam, NL

(d) EIM Business Policy Research, Zoetermeer, NL

(e) Southern Methodist University, Cox School of Business, Department of Strategy and Entrepreneurship, P.O. Box 750333, Dallas, TX 75275-0333, USA; Email:

mminniti@cox.smu.edu, Tel.: +1-214-7683145, Fax: +1-214-7684099 


\title{
Unemployment benefits crowd out nascent entrepreneurial activity
}

\begin{abstract}
Analyzing a cross-country panel of 16 OECD countries from 2002 to 2005, we find that higher unemployment benefits crowd out nascent entrepreneurial activity. Our results hold regardless of entrepreneurial motivation (necessity or opportunity) and entrepreneurial type (imitative or innovative).
\end{abstract}

JEL Codes: M13, J23, J65

Keywords: Entrepreneurship, Business Startups, Unemployment Benefits

\section{Introduction}

Although some evidence exists of a negative relationship between unemployment benefits and established self-employment (Parker and Robson, 2004), the relationship between unemployment benefits and start-up activity remains unclear. This is largely due to the lack of appropriate data since such a relationship can be properly understood only by looking at individuals who are actually in the process of starting a business. In other words, by considering all individuals who attempt to start a business rather than focusing only on those who have succeeded. Thank to new available data, we fill this gap by focusing on nascent rather than established entrepreneurship thereby capturing the effects of unemployment benefits on start-up propensity. 
Using data for 16 developed countries, we provide robust empirical evidence that generous unemployment benefits are negatively related to entrepreneurial activity. We show this to be true regardless of entrepreneurial motivation and type. To the extent that entrepreneurship is important for growth, our results suggest that unemployment benefits can generate a costly crowding out effect.

\section{Data}

Table 1 describes the data used in our analysis. Annual data on nascent entrepreneurial activity are taken from the Global Entrepreneurship Monitor (GEM) study. Every year, GEM conducts a representative population survey of at least 2000 people in each participating country. Individuals classify as nascent entrepreneurs if they claim to be engaged in starting a business they will at least partially own and that has paid wages or profits for no more than 6 months (Reynolds et al., 2005).

GEM data allow us to divide nascent entrepreneurs between those who are starting a business to pursue a profitable opportunity but could be otherwise employed (opportunity entrepreneurs), and those who are starting because no better employment option is available (necessity entrepreneurs). The average share of necessity nascent entrepreneurs across countries and time in our sample is $14 \%$.

In an alternative, entrepreneurs may be distinguished between innovators, who consider starting a business because of the monopolistic rents generated by their innovation, and imitators, who replicate existing businesses. GEM data allow us to divide nascent entrepreneurs between those who have many competitors and whose technology and product or service are already established (imitative entrepreneurs) and those who have introduced at least some innovation (innovative entrepreneurs) (Koellinger, 2008). The average share of purely imitative nascent entrepreneurs across countries and time in our sample is $27 \%$.

Annual data on unemployment rates and public out-of-work income maintenance and support for the same countries and years are taken from the OECD Employment Outlook (2005, 2006, 2007). 
The average generosity of unemployment benefits at the individual level is approximated by an index obtained by dividing the public spending on out-of-work income maintenance and support, measured in percent of GDP, by one plus the current unemployment rate. This index controls for the fact that an increase in unemployment rises public spending on out-of-work income maintenance and support without necessarily increasing unemployment benefits at the individual level. A high index value suggests generous average unemployment benefits compared to the national income. Unfortunately, our proxy for unemployment benefits does not capture possible differences in support schemes enjoyed by formerly employed and self-employed although such differences may be important (Hessels et al., 2007).

\section{Analysis}

We analyze a balanced cross-country panel with 16 countries and four annual observations (2002 to 2005) using random and fixed effects linear models that control for unobserved heterogeneity across countries (Wooldridge, 2002). Thus, we rule out alternative explanations for the estimated coefficients which might be due to unobserved heterogeneity. We estimate two alternative models with different measures for the generosity of unemployment benefits, one using the unemployment support index and another using the original share of public out-of-work income maintenance and support as percent of GDP. All regression results are qualitatively identical for both measures.

Table 2 shows regression results for the prevalence of nascent entrepreneurial activity across countries and time. The results suggest that high levels of unemployment benefits crowd out nascent entrepreneurial activity. Unemployment benefits are negatively associated to nascent entrepreneurial activity and highly significant in all models. Specification tests suggest that unobserved heterogeneity is highly significant and the difference in coefficients between random and fixed effects is not significant according to the Hausman test, thus supporting the random effects specification.

In Table 3, necessity nascent entrepreneurs are excluded. Our results show again a significant negative effect of unemployment benefits. Thus, the results suggest that higher unemployment 
benefits influence negatively even the share of individuals trying to start businesses because they perceive desirable opportunities. Furthermore, Table 4 shows that the share of opportunity and necessity entrepreneurs is unaffected by variations in unemployment benefits.

We now turn to the distinction between innovative and imitative entrepreneurs. In Table 5, imitative nascent entrepreneurs are excluded. Again, our results show a significant negative effect of unemployment benefits. This suggests that generous unemployment benefits crowd out innovative entrepreneurial activity.

In addition, Table 6 shows no influence of unemployment benefits on the ratio of innovative to imitative nascent entrepreneurs. Across the countries in our sample, such ratio is about 7 to 3 on average, with significant fluctuations across countries and time. Unemployment levels, however, do affect the ratio: Not surprisingly, higher levels of unemployment are associated with lower shares of innovative and higher shares of purely imitative nascent entrepreneurs.

\section{Conclusion}

Our results fill a gap in the employment choice literature by providing evidence that generous unemployment benefits are negatively related to nascent entrepreneurship and that this is true regardless of entrepreneurial motivation and type. In other words, higher unemployment benefits seem to reduce the overall entrepreneurial propensity of a country. If entrepreneurial activity is important for economic growth, our results suggest that the opportunity costs of unemployment benefits may be higher than what is normally assumed in the labor economics studies. 


\section{References}

Hessels, J., A. van Stel, P. Brouwer, S. Wennekers, 2007, Social security arrangements and earlystage entrepreneurial activity, Comparative Labor Law and Policy Journal 13, 37-46.

Koellinger, P., 2008, Why are some entrepreneurs more innovative than others? Small Business Economics Journal, forthcoming.

Parker, S.C., Robson, M.T., 2004, Explaining international variations in self-employment: Evidence from a panel of OECD countries, Southern Economic Journal 71(2), 287-301.

OECD, 2007, 2006, 2005, OECD Unemployment Outlook. (OECD Publishing, Paris).

Reynolds, P., Bosma, N., Autio, E., Hunt, S., de Bono, N., Servais, I., Lopez-Garcia, P., Chin, N., 2005, Global Entrepreneurship Monitor: Data collection design and implementation 1998-2003, Small Business Economics Journal, 24, 205-231.

Wooldridge, J., 2002, Econometric Analysis of Cross Section and Panel Data. (Cambridge, MA and London, England: MIT Press). 
Table 1: Four year averages for nascent entrepreneurial activity, unemployment, and public unemployment expenditures in 16 countries, 2002-2005

\begin{tabular}{|c|c|c|c|c|c|c|}
\hline Country & $\begin{array}{l}\text { Nascent } \\
\text { entrepreneurs } \\
\text { (\% of adult pop } \\
18-64)^{*}\end{array}$ & $\begin{array}{l}\text { Share of } \\
\text { opportunity } \\
\text { nascent } \\
\text { entrepreneurs } \\
\text { (\% of adult } \\
\text { nascent } \\
\text { entrepreneurs)* }\end{array}$ & $\begin{array}{l}\text { Share of } \\
\text { innovative } \\
\text { nascent } \\
\text { entrepreneurs } \\
\text { (\% of adult } \\
\text { nascent } \\
\text { entrepreneurs)* }\end{array}$ & $\begin{array}{l}\text { Unemployment } \\
\text { rate (\% of adult } \\
\text { pop 18-64) }{ }^{+}\end{array}$ & $\begin{array}{l}\text { Unemployment } \\
\text { support }^{1}(\% \text { of } \\
\text { GDP) }\end{array}$ & $\begin{array}{l}\text { Unemployment } \\
\text { support index }\end{array}$ \\
\hline Australia & 5.73 & 87 & 77 & 5.8 & 0.69 & 0.65 \\
\hline Belgium & 2.37 & 91 & 68 & 8.1 & 1.96 & 1.81 \\
\hline Canada & 5.24 & 85 & 76 & 7.3 & 0.71 & 0.66 \\
\hline Denmark & 2.90 & 94 & 84 & 5.1 & 1.81 & 1.72 \\
\hline Finland & 2.96 & 88 & 67 & 8.8 & 1.53 & 1.41 \\
\hline France & 3.05 & 73 & 68 & 9.3 & 1.57 & 1.44 \\
\hline Germany & 3.99 & 75 & 70 & 9.1 & 2.23 & 2.05 \\
\hline Ireland & 4.84 & 81 & 78 & 4.5 & 0.80 & 0.76 \\
\hline Japan & 0.92 & 83 & 68 & 5.0 & 0.47 & 0.45 \\
\hline Netherlands & 2.59 & 90 & 72 & 3.9 & 1.98 & 1.90 \\
\hline New Zealand & 8.41 & 86 & 73 & 4.4 & 0.67 & 0.64 \\
\hline Norway & 4.14 & 92 & 74 & 4.4 & 0.82 & 0.78 \\
\hline Spain & 2.60 & 85 & 56 & 10.5 & 1.44 & 1.31 \\
\hline Sweden & 1.66 & 90 & 76 & 6.0 & 1.19 & 1.12 \\
\hline UK & 2.66 & 86 & 80 & 4.9 & 0.25 & 0.23 \\
\hline USA & 7.66 & 86 & 76 & 5.6 & 0.34 & 0.32 \\
\hline \multicolumn{7}{|c|}{$\begin{array}{l}{ }^{*} \text { Data from Global Entrepreneurship Monitor } \\
{ }^{+} \text {Data from OECD Employment Outlook } \\
{ }^{1} \text { Public out-of-work income maintenance and support } \\
\left.{ }^{2} \text { Support index }=\text { (Public out-of-work income maintenance and support in \% of GDP }\right)^{+} /(1+\text { Unemployment rate in \% of total } \\
\text { labour force) }{ }^{+}\end{array}$} \\
\hline
\end{tabular}


Table 2: Regression results on prevalence of nascent entrepreneurial activity across 16 countries, 2002-2005

\begin{tabular}{|c|c|c|c|c|c|c|c|c|}
\hline & \multicolumn{2}{|c|}{ Random effects } & \multicolumn{2}{|c|}{ Fixed effects } & \multicolumn{2}{|c|}{ Random effects } & \multicolumn{2}{|c|}{ Fixed effects } \\
\hline Unemployment support index $^{+}$ & $-176.7^{* *}$ & $(84.36)$ & $-294.6^{*}$ & $(163.3)$ & - & - & - & - \\
\hline Unemployment support in \% of GDP & - & - & - & - & $-1.67 * *$ & $(0.80)$ & $-2.83 *$ & $(1.57)$ \\
\hline Unemployment rate & 0.13 & $(0.18)$ & 0.35 & $(0.27)$ & 0.15 & $(0.19)$ & 0.39 & $(0.28)$ \\
\hline Constant & $4.64 * *$ & $(1.15)$ & $4.52 * *$ & $(1.43)$ & $4.52 * *$ & $(1.14)$ & $4.36 * *$ & $(1.40)$ \\
\hline \multicolumn{9}{|l|}{ Model diagnostics } \\
\hline Hausman Test (Prob $>$ Chi2) & \multicolumn{4}{|l|}{0.94} & \multicolumn{4}{|l|}{0.94} \\
\hline $\mathrm{R} 2$ & \multicolumn{2}{|l|}{0.13} & \multicolumn{2}{|l|}{0.11} & \multicolumn{2}{|l|}{0.13} & \multicolumn{2}{|l|}{0.11} \\
\hline Rho & \multicolumn{2}{|l|}{$0.87 * *$} & \multicolumn{2}{|l|}{$0.88^{* *}$} & \multicolumn{2}{|l|}{$0.87 * *$} & \multicolumn{2}{|l|}{$0.88^{* *}$} \\
\hline $\begin{array}{l}\mathrm{N}=64 \text {. Standard errors in parentheses } \\
\text { All models include time dummies. } \\
* * \text { significant at }>95 \% \text { confidence } \\
* \text { significant at }>90 \% \text { confidence }\end{array}$ & & & & & & & & \\
\hline
\end{tabular}

Table 3: Regression results on prevalence of opportunity nascent entrepreneurial activity across 16 countries, $2002-2005$

\begin{tabular}{|c|c|c|c|c|c|c|c|c|}
\hline & \multicolumn{2}{|c|}{ Random effects } & \multicolumn{2}{|c|}{ Fixed effects } & \multicolumn{2}{|c|}{ Random effects } & \multicolumn{2}{|c|}{ Fixed effects } \\
\hline Unemployment support index $^{+}$ & $-146.7 * *$ & $(69.54)$ & $-247.4^{*}$ & $(133.0)$ & - & - & - & - \\
\hline Unemployment support in \% of GDP & - & - & - & - & $-1.38 * *$ & $(0.66)$ & $-2.36 *$ & $(1.28)$ \\
\hline Unemployment rate & 0.55 & $(0.15)$ & 0.23 & $(0.22)$ & 0.07 & $(0.15)$ & 0.26 & $(0.23)$ \\
\hline Constant & $4.23 * *$ & $(0.95)$ & $4.19 * *$ & $(1.17)$ & $4.13 * *$ & $(0.94)$ & $4.04 * *$ & $(1.14)$ \\
\hline \multicolumn{9}{|l|}{ Model diagnostics } \\
\hline Hausman Test (Prob > Chi2) & \multicolumn{4}{|l|}{0.94} & \multicolumn{4}{|l|}{0.93} \\
\hline $\mathrm{R} 2$ & \multicolumn{2}{|l|}{0.15} & \multicolumn{2}{|l|}{0.12} & \multicolumn{2}{|l|}{0.15} & \multicolumn{2}{|l|}{0.12} \\
\hline Rho & \multicolumn{2}{|l|}{0.87} & \multicolumn{2}{|l|}{0.89} & \multicolumn{2}{|l|}{0.87} & \multicolumn{2}{|l|}{0.89} \\
\hline \multicolumn{9}{|l|}{$\begin{array}{l}\mathrm{N}=64 \text {. Standard errors in parentheses. } \\
\text { All models include time dummies. } \\
* * \text { significant at }>95 \% \text { confidence } \\
* \text { significant at }>90 \% \text { confidence }\end{array}$} \\
\hline
\end{tabular}

Table 4: Regression results on the share of opportunity vs. necessity nascent entrepreneurs across 16 countries, $2002-2005$

\begin{tabular}{|c|c|c|c|c|c|c|c|c|}
\hline s & \multicolumn{2}{|c|}{ Random effects } & \multicolumn{2}{|c|}{ Fixed effects } & \multicolumn{2}{|c|}{ Random effects } & \multicolumn{2}{|c|}{ Fixed effects } \\
\hline Unemployment support index $^{+}$ & 1.65 & $(2.54)$ & -7.07 & $(12.5)$ & - & - & - & - \\
\hline Unemployment support in \% of GDP & - & - & - & - & 0.02 & $(0.02)$ & -0.07 & $(0.12)$ \\
\hline Unemployment rate & -0.02 & $(0.01)$ & -0.01 & $(0.02)$ & -0.02 & $(0.01)$ & -0.01 & $(0.02)$ \\
\hline Constant & $0.94 * *$ & $(0.04)$ & $1.01^{* *}$ & $(0.11)$ & $0.94 * *$ & $(0.04)$ & $1.01^{* *}$ & $(0.11)$ \\
\hline \multicolumn{9}{|l|}{ Model diagnostics } \\
\hline Hausman Test (Prob $>$ Chi2) & \multicolumn{4}{|l|}{0.98} & \multicolumn{4}{|l|}{0.98} \\
\hline R2 & \multicolumn{2}{|l|}{0.14} & \multicolumn{2}{|l|}{0.04} & 0.14 & & \multicolumn{2}{|l|}{0.04} \\
\hline Rho & \multicolumn{2}{|l|}{0.36} & \multicolumn{2}{|l|}{0.60} & 0.36 & & \multicolumn{2}{|l|}{0.60} \\
\hline $\begin{array}{l}\mathrm{N}=64 \text {. Standard errors in parentheses } \\
\text { All models include time dummies. } \\
* * \text { significant at }>95 \% \text { confidence } \\
* \text { significant at }>90 \% \text { confidence }\end{array}$ & & & & & & & & \\
\hline
\end{tabular}


Table 5: Regression results on prevalence of innovative nascent entrepreneurial activity across 16 countries, 2002-2005

\begin{tabular}{|c|c|c|c|c|c|c|c|c|}
\hline & \multicolumn{2}{|c|}{ Random effects } & \multicolumn{2}{|c|}{ Fixed effects } & \multicolumn{2}{|c|}{ Random effects } & \multicolumn{2}{|c|}{ Fixed effects } \\
\hline Unemployment support index $^{+}$ & $-133.3^{* *}$ & $(63.4)$ & $-221.3^{*}$ & $(123.5)$ & - & - & - & - \\
\hline Unemployment support in \% of GDP & - & - & - & - & $-1.26 * *$ & $(0.60)$ & $-2.11 *$ & $(1.18)$ \\
\hline Unemployment rate & 0.02 & $(0.14)$ & 0.17 & $(0.20)$ & 0.04 & $(0.14)$ & 0.19 & $(0.21)$ \\
\hline Constant & $3.90 * *$ & $(0.86)$ & $3.91 * *$ & $(0.00)$ & $3.81 * *$ & $(0.86)$ & $3.78^{* *}$ & $(1.05)$ \\
\hline \multicolumn{9}{|l|}{ Model diagnostics } \\
\hline Hausman Test (Prob $>$ Chi2) & \multicolumn{4}{|l|}{0.96} & \multicolumn{4}{|l|}{0.96} \\
\hline $\mathrm{R} 2$ & \multicolumn{2}{|l|}{0.17} & \multicolumn{2}{|l|}{0.14} & \multicolumn{2}{|l|}{0.17} & \multicolumn{2}{|l|}{0.14} \\
\hline Rho & \multicolumn{2}{|l|}{$0.87 * *$} & \multicolumn{2}{|l|}{$0.88^{* *}$} & \multicolumn{2}{|l|}{$0.87 * *$} & \multicolumn{2}{|l|}{$0.88^{* *}$} \\
\hline $\begin{array}{l}\mathrm{N}=64 \text {. Standard errors in parentheses } \\
\text { All models include time dummies. } \\
* * \text { significant at }>95 \% \text { confidence } \\
* \text { significant at }>90 \% \text { confidence }\end{array}$ & & & & & & & & \\
\hline
\end{tabular}

Table 6: Regression results on the share of innovative vs. imitative nascent entrepreneurs across 16 countries, $2002-2005$

\begin{tabular}{|c|c|c|c|c|c|c|c|c|}
\hline & \multicolumn{2}{|c|}{ Random effects } & \multicolumn{2}{|c|}{ Fixed effects } & \multicolumn{2}{|c|}{ Random effects } & \multicolumn{2}{|c|}{ Fixed effects } \\
\hline Unemployment support index $^{+}$ & 0.34 & $(2.32)$ & 6.11 & $(15.0)$ & - & - & - & - \\
\hline Unemployment support in \% of GDP & - & - & - & - & 0.00 & $(0.02)$ & 0.06 & $(0.14)$ \\
\hline Unemployment rate & $-0.02 * *$ & $(0.01)$ & -0.02 & $(0.02)$ & $-0.02 * *$ & $(0.01)$ & -0.02 & $(0.03)$ \\
\hline Constant & $0.85 * *$ & $(0.04)$ & $0.78^{* *}$ & $(0.13)$ & $0.85^{* *}$ & $(0.04)$ & $0.78^{* *}$ & $(0.00)$ \\
\hline \multicolumn{9}{|l|}{ Model diagnostics } \\
\hline Hausman Test (Prob > Chi2) & \multicolumn{4}{|l|}{1.00} & \multicolumn{4}{|l|}{1.00} \\
\hline $\mathrm{R} 2$ & \multicolumn{2}{|l|}{0.34} & \multicolumn{2}{|l|}{0.18} & \multicolumn{2}{|l|}{0.34} & \multicolumn{2}{|l|}{0.18} \\
\hline Rho & \multicolumn{2}{|l|}{0.18} & \multicolumn{2}{|l|}{$0.41 *$} & 0.18 & & \multicolumn{2}{|l|}{$0.41 *$} \\
\hline $\begin{array}{l}\mathrm{N}=64 \text {. Standard errors in parentheses } \\
\text { All models include time dummies. } \\
* * \text { significant at }>95 \% \text { confidence } \\
* \text { significant at }>90 \% \text { confidence }\end{array}$ & & & & & & & & \\
\hline
\end{tabular}




\section{Publications in the ERIM Report Series Research* in Management}

\section{ERIM Research Program: "Organizing for Performance"}

2008

Explaining Preferences and Actual Involvement in Self-Employment: New Insights into the Role of Gender Ingrid Verheul, Roy Thurik and Isabel Grilo ERS-2008-003-ORG

http://hdl.handle.net/1765/10979

Public Finance in China since the Late Qing Dynasty

Barbara Krug

ERS-2008-005-ORG

http://hdl.handle.net/1765/11287

Overoptimism among Founders: The Role of Information and Motivation

Ingrid Verheul and Martin Carree

ERS-2008-008-ORG

http://hdl.handle.net/1765/11557

Do Foreign Greenfields Outperform Foreign Acquisitions or Vice Versa? An Institutional Perspective Arjen H.L. Slangen and Jean-François Hennart

ERS-2008-009-ORG

http://hdl.handle.net/1765/11558

Unemployment Benefits Crowd Out Nascent Entrepreneurial Activity

Philipp Koellinger and Maria Minniti

ERS-2008-012-ORG

http://hdl.handle.net/1765/11808

Acceleration of Technology Adoption within Firms: Empirical Evidence from the Diffusion of E-business Technologies Philipp Koellinger and Christian Schade

ERS-2008-013-ORG

http://hdl.handle.net/1765/11809

* A complete overview of the ERIM Report Series Research in Management: https://ep.eur.nl/handle/1765/1

ERIM Research Programs:

LIS Business Processes, Logistics and Information Systems

ORG Organizing for Performance

MKT Marketing

F\&A Finance and Accounting

STR Strategy and Entrepreneurship 